\title{
Influence of Different Pretreatments on Hot air and Microwave-Hot Air Combined Drying of White Sweet Cherry
}

\author{
Meric Simsek $^{1, a, *}$, Özge Süfer ${ }^{1, b}$ \\ ${ }^{I}$ Department of Food Engineering, Osmaniye Korkut Ata University, 80000 Osmaniye, Turkey \\ *Corresponding author \\ A R T I C L E I N F O A B S T R A C T \\ Research Article \\ Microwave (MW)-hot air (HA) combined drying was applied to white sweet cherries besides solely \\ $\mathrm{HA}$ drying at 50,60 and $70^{\circ} \mathrm{C}$ in the presence of citric acid, sucrose and freezing pretreatment in \\ this study. Single power level of MW $(90 \mathrm{~W})$ was chosen, and drying behavior of all samples was \\ modelled by using eleven thin layer equations. Two-term, rational and sigmoid models were the \\ Received : $18 / 05 / 2021$ \\ Accepted : 14/06/2021 \\ most suitable models for describing drying phenomena. Effective moisture diffusivities $\left(D_{\text {eff }}\right)$ \\ ranged from $1.724 \times 10^{-10}$ to $5.173 \times 10^{-10} \mathrm{~m}^{2} / \mathrm{s}$ in HA drying and from $4.260 \times 10^{-10}$ to $1.805 \times 10^{-9} \mathrm{~m}^{2} / \mathrm{s}$ \\ in MW-HA drying. Activation energies $\left(\mathrm{E}_{\mathrm{a}}\right)$ were between 2.785 and $30.541 \mathrm{~kJ} / \mathrm{mol}$ and 6.929 and \\ $42.101 \mathrm{~kJ} / \mathrm{mol}$ for HA and MW-HA drying techniques, respectively. Total color change $(\Delta \mathrm{E})$ levels \\ of the outer surface of dried cherries were generally higher than the ones of inner surface. Freezing \\ pretreatment had a comparably lower enhancing effect on the total phenolic content (TPC) of HA \\ Keywords: \\ White sweet cherry \\ dried white sweet cherries compared to fresh sample. The TPC of freezing pretreated and HA dried \\ Drying \\ at $50^{\circ} \mathrm{C}$ and $\mathrm{HA}$ dried at $70^{\circ} \mathrm{C}$ control samples were $1.481 \pm 0.398 \mathrm{mg}$ gallic acid equivalent \\ Microwave \\ Pre-treatment \\ Total phenolic content \\ $(\mathrm{GAE}) / \mathrm{g}$ dry matter $(\mathrm{DM})$ and $6.181 \pm 0.012 \mathrm{mg} \mathrm{GAE} / \mathrm{g} \mathrm{DM}$ as the minimum and maximum, \\ respectively. These values were determined as $4.183 \pm 1.728$ and $8.240 \pm 0.502 \mathrm{mg}$ GAE/g DM that \\ were belonged to MW-HA dried at $50^{\circ} \mathrm{C}$ control and freezing pretreated $\mathrm{MW}-\mathrm{HA}$ dried at $70^{\circ} \mathrm{C}$ \\ samples in combined procedure, respectively.
}

\section{Introduction}

White sweet cherry (Prunus avium L. stark gold) is prone to deterioration and browning during the storage due to its high moisture, sugar, and polyphenol content. Its phenolic rich content may present to several health benefits involving reduction in inflammatory biomarkers and cancer growth and antioxidant effect (Gonçalves et al., 2020). Antioxidant biomaterials are used as supplements to decrease oxidative stress which is defined as imbalance between endogenous oxidants and antioxidants, in human body (Finaud et al., 2006; Mujic et al., 2010; Sevindik et al., 2017; Mohammed et al., 2020).

Like most fruits white sweet cherry is available for short period of time, drying can be applied to increase its availability through out of season. As known, drying is a commonly used post-harvest technique to hamper microbial growths and chemical reactions in the material during the storage. Different drying techniques such as air, freeze and vacuum were applied to cherries in previous studies (Doymaz and İsmail, 2011; Pirone et al., 2014; Franceschinis et al., 2015; Vakula et al., 2020).
Among these methods, hot air (HA) drying is one of the most preferred techniques due to its low cost; however, its long drying time can affect adversely the retention of bioactive compounds. This drawback can be eliminated using microwave (MW) drying, but MW drying has several problems such as non-uniform heating and high operating cost. Also, long MW drying can damage the texture and change chemical compositions (Miraei Ashtiani et al., 2018); therefore, in order to overcome these problems, MW and HA can be combined to obtain fast and uniform drying with high quality product (Zhao et al., 2014; Wang et al., 2018). The combination of MW and HA drying has been applied for various products such as carrot (Zhao et al., 2014), cranberry (Staniszewska et al., 2020) and mushroom (Wang et al., 2019). In addition, the pretreatments can be used prior to drying to improve the physicochemical and bioactive properties of dried food. Pretreatments selected for this study were the immersion in citric acid and sucrose solution and freezing, which help to remove the water and enhance the color as well the texture. 
Drying kinetics analysis is crucial which enables mathematically modelling the drying process. The thin layer models are useful for the identifying the drying parameters. They are used for optimizing or designing novel drying processes (Miraei Ashtiani et al., 2018). There have been no studies investigating the drying of white sweet cherry using the combination of MW and HA drying.

The objectives of this study were to show the effect of different pretreatments (citric acid, sucrose and freezing) on the drying kinetics and bioactive properties of white sweet cherry dried by MW and HA drying combination and compare with conventional HA drying.

\section{Material and Method}

\section{Material}

Sweet cherries $(P$. avium $)$ L. stark gold were obtained from a local grocery in Bahçe, Osmaniye, Turkey in 2019. The initial moisture content of cherries was determined as $82.81 \pm 0.83 \%$ on wet basis according to AOAC (1990).

\section{Pretreatments}

Apart from control, three pretreatments were applied prior to drying: citric acid, sucrose and freezing. In the application of citric acid and sucrose, sweet cherries were immersed in $10 \%$ (weight/volume, w/v) citric acid (Pirone et al., 2014) and 60\% (w/v) sucrose solutions (Zhao et al., $2013)$, respectively at a ratio of $2: 7(\mathrm{w} / \mathrm{v})$ for $30 \mathrm{~min}$ at 25 $\pm 1{ }^{\circ} \mathrm{C}$. In freezing, sweet cherries were frozen and stored in a freezer section of a refrigerator (Arçelik, $570504 \mathrm{MB}$, Turkey) at $-18^{\circ} \mathrm{C}$ until drying experiments (Dandamrongrak et al., 2003). Before drying, sweet cherries were cut into two pieces and their pits were removed.

\section{Hot Air Drying}

Sweet cherries were dried by natural convection using an oven (Memmert UN55, Germany) at 50, 60 and $70^{\circ} \mathrm{C}$. The dimensions and volume of the oven were $400 \times 400 \times$ $330 \mathrm{~mm}$ and $53 \mathrm{~L}$, respectively. Oven was run as idle during $30 \mathrm{~min}$, until the steady-state conditions were reached. The weight of sweet cherries (initial weight of 38 g) in glass petri dishes was measured using a digital balance (OHAUS, Pioneer ${ }^{\mathrm{TM}}$, PA 114, USA) at the $15 \mathrm{~min}$ intervals during the first hour and then at $30 \mathrm{~min}$ intervals until the completion of drying. When the weight of sweet cherries became constant, drying process was terminated. All experiments were performed in duplicate.

\section{Microwave-Hot-Air Drying Combination}

The sweet cherries were dried using two stage drying process. Firstly, the cherries placed on a rotating plate $(\mathrm{D}=245 \mathrm{~mm})$ was dried using kitchen-type $\mathrm{MW}$ oven (Bosch, HMT84G, Germany) at $90 \mathrm{~W}$ for nearly $22 \mathrm{~min}$ in a discontinuous mode. The low power of $90 \mathrm{~W}$ was selected to eliminate the possible occurrence of burnings and the color loss in the material. Average moisture ratio (MR) of samples was recorded as $0.324 \pm 0.084$ before HA drying application. The weight of samples was measured at 5 min of intervals by a digital balance (OHAUS, Pioneer $^{\mathrm{TM}}$, PA 114, USA). The MW oven had the dimensions of $513 \mathrm{~mm} \times 408 \mathrm{~mm} \times 305 \mathrm{~mm}$ with $25 \mathrm{~L}$ internal capacity. After MW drying, the sweet cherries were exposed to $\mathrm{HA}$ drying at 50,60 and $70^{\circ} \mathrm{C}$ and the weight data was recorded at $30 \mathrm{~min}$ intervals. All experiments were performed in duplicate.

\section{Mathematical Modeling of Drying}

The experimental drying data from MW and MW-HA drying was fitted to the most used thin layer drying models in the literature (Table 1). The dimensionless MR was calculated from the moisture content $\left(\mathrm{M}_{\mathrm{t}}\right)$ and initial moisture content $\left(\mathrm{M}_{0}, \mathrm{~kg}_{\text {water }} \mathrm{kg}^{-1} \mathrm{DM}\right)$ as stated in Eq. (1).

$$
\mathrm{MR}=\frac{M_{t}}{M_{0}}
$$

The determination coefficient $\left(\mathrm{R}^{2}\right)$, reduced chi-square $\left(\chi^{2}\right)$ and root mean square error (RMSE) were used to determine the goodness of the fit of the mathematical models. The higher $\mathrm{R}^{2}$, lower $\chi^{2}$ and RSME were used to define the most appropriate model for drying process. The following equations were used to calculate the aforesaid parameters:

$$
\begin{aligned}
& \chi^{2}=\frac{\sum_{i=1}^{N}\left(M R_{\text {exp }, i}-M R_{\text {pre }, i}\right)^{2}}{N-z} \\
& \mathrm{RMSE}=\left[\frac{1}{N} \sum_{i=1}^{N}\left(M R_{\text {exp }, i}-M R_{\text {pre }, i}\right)^{2}\right]^{1 / 2}
\end{aligned}
$$

where $\mathrm{MR}_{\text {exp,i }}$ and $\mathrm{MR}_{\text {pre,i }}$ are experimental and predicted $\mathrm{MR}$ at $\mathrm{I}, \mathrm{N}$ is the number of experimental data and $\mathrm{z}$ is the number of constant.

\section{Effective Moisture Diffusivity}

Fick's second law was used to calculate the effective moisture diffusivity $\left(D_{\text {eff }}, \mathrm{m}^{2} \mathrm{~s}^{-1}\right.$ ) given in Eq. (4) (Doymaz and Kipcak, 2018). Uniform moisture distribution, negligible shrinkage and infinite slab geometry were assumed (Crank, 1975).

$$
\begin{aligned}
& \frac{\partial M R}{\partial t}=\mathrm{D}_{\mathrm{eff}} \nabla^{2} \mathrm{MR} \\
& \mathrm{MR}=\frac{8}{\pi^{2}} \sum_{n=1}^{\infty} \frac{1}{n^{2}} \exp \left[-(2 n-1)^{2} \pi^{2} \frac{D_{e f f} t}{R^{2}}\right]
\end{aligned}
$$

Eq. (5) was converted to logarithmic form in Eq. (6).

$$
\ln (\mathrm{MR})=\ln \left(\frac{8}{\pi^{2}}\right)-\left(\frac{\pi^{2} D_{e f f} t}{4 L^{2}}\right)
$$

where $\mathrm{L}$ was the half thickness of sample (m).

\section{Activation Energy}

Activation energy $\left(\mathrm{E}_{\mathrm{a}}, \mathrm{kJ} \mathrm{mol}^{-1}\right)$ of moisture diffusion was determined using Arrhenius relationship as stated in Eq. (7) (Doymaz and Kipcak, 2018).

$$
\mathrm{D}_{\mathrm{eff}}=\mathrm{D}_{0} \exp \left(\frac{-E a}{R T}\right)
$$

where $\mathrm{D}_{0}$ was the pre-exponential factor $\left(\mathrm{m}^{2} \mathrm{~s}\right)$, R was the universal gas constant $\left(\mathrm{J} \mathrm{mol}^{-1} \mathrm{~K}^{-1}\right)$ and $\mathrm{T}(\mathrm{K})$ was the temperature. 


\section{Color}

$L^{*}$ (lightness), $a^{*}$ (redness-greenness) and $b^{*}$ (yellowness-blueness) of sweet cherries were measured using a portable chroma meter (Konica Minolta, CR-400, Japan). Measurements were performed in triplicate. Total color change $(\Delta \mathrm{E})$ and yellowness index (YI) (Pathare et al., 2013) were calculated using Eq. (8) and (9):

$$
\Delta \mathrm{E}=\sqrt{\left(L^{*}-L_{r e f}\right)^{2}+\left(a^{*}-a_{r e f}\right)^{2}+\left(b^{*}-b_{r e f}\right)^{2}}
$$

where $L^{*}, a^{*}$ and $b^{*}$ were the color parameters of the dried sweet cherry and $L_{r e f}, a_{r e f}$ and $b_{\text {ref }}$ were the color parameters of the fresh sweet cherry.

$$
\mathrm{YI}=\frac{142.86 \times b^{*}}{L^{*}}
$$

\section{Total Phenolic Content}

The procedure followed by Bennett et al. (2011) was modified and phenolic compounds were extracted from the sweet cherry sample ( $1 \mathrm{~g})$ using $80 \%$ methanol solution (v/v) in the ultrasonic bath (J.P. Selecta Ultrasons HD, Spain) for $20 \mathrm{~min}$ at $25^{\circ} \mathrm{C}$. Afterwards, this mixture was centrifuged, and supernatants were collected as the extracts. The extracts were used freshly in total phenolic content (TPC) analysis. TPC of sweet cherries was determined using Folin-Ciocalteu method at $760 \mathrm{~nm}$ using a spectrophotometer (Shimadzu, UV-1800, Japan) (Li et al., 2015) and the results were given as mg gallic acid equivalent (GAE) per g dry matter (DM). All tests were conducted in triplicate.

\section{Statistical Analysis}

The analyses of linear and non-linear regression were performed by Origin Pro 2016 (Origin-Lab, USA) software (trial version) for drying kinetics. Data was analyzed using one-way analysis of variance (ANOVA) by trial version of SPSS package program (IBM, USA). Duncan test applied to define differences among the TPC of samples $(\mathrm{P}<0.05)$.

Table 1. Thin layer drying models used in this study

\begin{tabular}{c|lll}
\hline Model number & \multicolumn{1}{|c}{ Model name } & \multicolumn{1}{c}{ Equation } \\
\hline 1 & Page & $\mathrm{MR}=\exp \left(-\mathrm{kt}^{\mathrm{n}}\right)$ & Reference \\
2 & Modified Page & $\mathrm{MR}=\exp (-\mathrm{kt})^{\mathrm{n}}$ & Overhults et al., 1973 \\
3 & Sigmoid & $\mathrm{MR}=\mathrm{a}+\frac{\mathrm{b}}{1+\mathrm{e}^{\mathrm{k}(\mathrm{t}-\mathrm{c})}}$ & Antal et al., 2011 \\
4 & Midilli et al. & $\mathrm{MR}=\mathrm{a} \exp \left(-\mathrm{kt} \mathrm{t}^{\mathrm{n}}\right)+\mathrm{bt}$ & Midilli et al., 2002 \\
5 & Henderson and Pabis & $\mathrm{MR}=\mathrm{a} \exp (-\mathrm{kt})$ & Henderson and Pabis, 1961 \\
6 & Two-term & $\mathrm{MR}=\mathrm{a} \exp (-\mathrm{kt})+\mathrm{b} \exp \left(-\mathrm{k}_{\mathrm{o}} \mathrm{t}\right)$ & Henderson, 1974 \\
7 & Wang-Singh & $\mathrm{MR}=1+\mathrm{at}+\mathrm{bt}^{2}$ & Wang and Singh, 1978 \\
8 & Parabolic & $\mathrm{MR}=\mathrm{a}+\mathrm{bt}+\mathrm{ct}^{2}$ & Sharma and Prasad, 2004 \\
9 & Cubic & $\mathrm{MR}=\mathrm{a}+\mathrm{bt}+\mathrm{ct}^{2}+\mathrm{dt}^{3}$ & Dalvand et al., 2012 \\
10 & Rational & $\mathrm{MR}=\frac{\mathrm{a}+\mathrm{bt}}{1+\mathrm{ct}+\mathrm{dt}^{2}}$ & Haghi and Angiz, 2007 \\
11 & Vega Galvez & $\mathrm{MR}=\mathrm{n}+\mathrm{k} \sqrt{\mathrm{t}}$ & Vega-Gálvez et al., 2008 \\
\hline
\end{tabular}

MR: Moisture ratio; a, b, c, d, k, $\mathrm{k}_{\mathrm{o}}, \mathrm{k}_{1}, \mathrm{n}$ : model parameters, t: time

\section{Results and Discussion}

\section{Drying}

Figure 1 shows drying times of white sweet cherries dehydrated by both two methods. Drying time of HA dried samples were longer than MW-HA dried ones, as expected because microwaves enable fast water evaporation due to ionic heat conduction and dipolar relaxation (Kumar and Karim, 2019). Operation times were ranged from 1160 to $3557 \mathrm{~min}$ for HA drying, and from 232 to $752 \mathrm{~min}$ for MWHA drying. When the temperature level increased, durations were also decreased. All pretreatment applications influenced process times in a desirable way, compared to intact. From this observation, it is concluded that the resistance of internal moisture transfer can be diminished by either citric acid or sucrose solution (Adiletta et al., 2018; Önal et al., 2019) except freezing. Among pretreated samples, frozen samples had the lowest drying time; however, samples with citric acid had the highest one. This can be resulted from the formation of ice crystals during freezing procedure by damaging the fruit tissue causing excess water to be thrown out of the tissues, while the thawing continues ( $\mathrm{Li}$ et al., 2018). The final moisture contents (\%) of control, citric acid, sucrose and freezing pretreated white sweet cherries were recorded as
$5.92 \pm 1.54,6.78 \pm 2.61,6.86 \pm 1.68$ and $6.33 \pm 0.74$ for HA dried samples and $5.20 \pm 1.47,7.74 \pm 3.03,6.06 \pm 1.20$ and $5.04 \pm 2.21$ for MW-HA dried ones on wet basis respectively, which were below $10 \%$, the critical moisture level for microbial risks.

Table 2 summarizes the findings of the best three thin layer drying models with their statistical outcomes. Two term (Henderson, 1974), rational (Haghi and Angiz, 2007) and sigmoid (Antal et al., 2011) models were qualified satisfactorily for the experimental drying data among the others listed in Table 1. These mathematical expressions had high $\mathrm{R}^{2}$ and low $\chi^{2}$ and RMSE values ranging between 0.91160 to $099880,0.00001$ to 0.00949 and 0.00185 to 0.08104 , respectively. Horuz et al. (2017) displayed that Verma and modified Logistic models were the most suitable models for describing both conventional and hybrid (microwave-convectional) drying of sour cherries. Szadzińska et al. (2019) showed that modified Page model (1949) was the best in predicting microwave- and ultrasound-assisted convective drying phenomena of raspberries. 


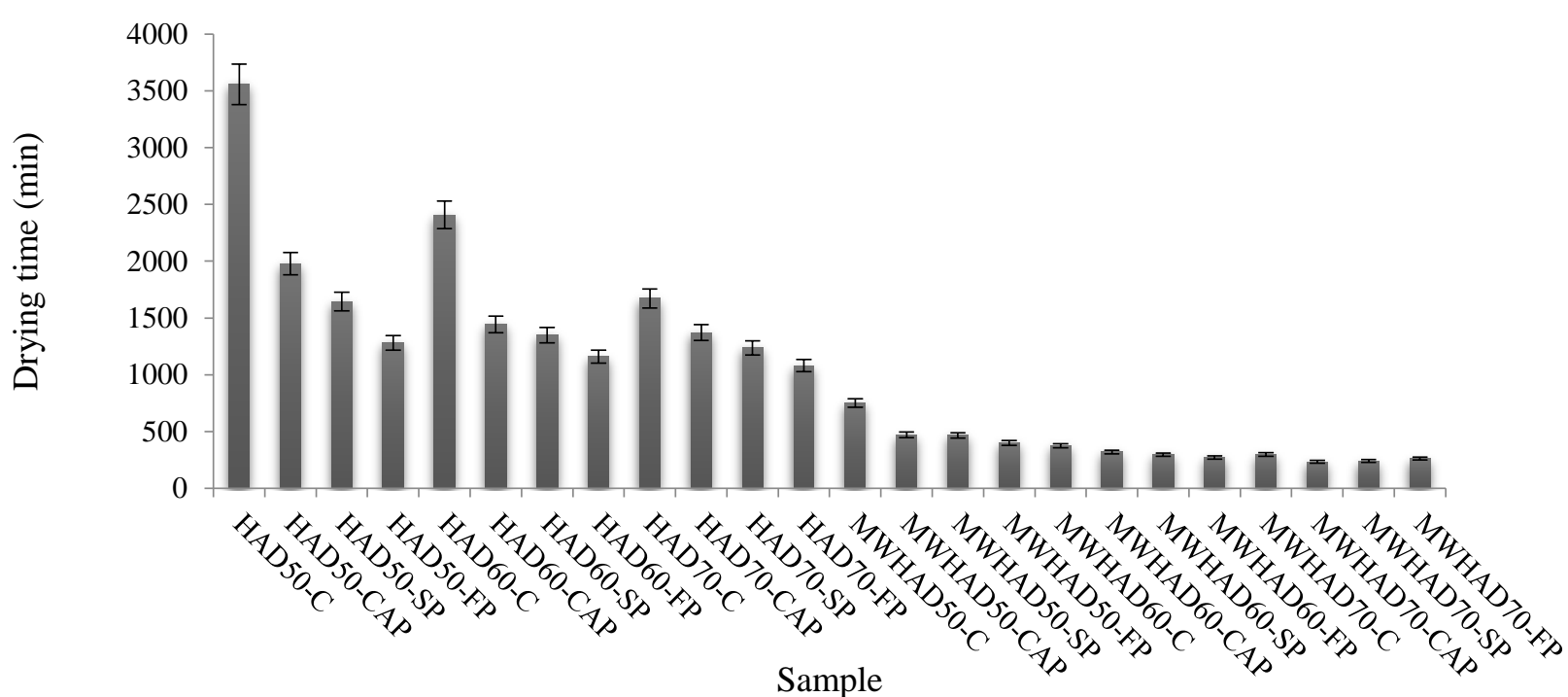

Figure 1. Drying times of white sweet cherries

HAD: Hot air dried, MWHAD: Microwave+hot air dried, 50, 60 and 70: Temperature levels $\left({ }^{\circ} \mathrm{C}\right), \mathrm{C}$ : Control, CAP: Citric acid pretreatment, SP: Sucrose pretreatment, FP: Freezing pretreatment

Table 2. The results of selected mathematical expressions applied to the data of both conventional and combination drying

\begin{tabular}{|c|c|c|c|c|c|c|c|c|c|c|}
\hline \multirow{2}{*}{$S$} & \multirow{2}{*}{ Model } & \multicolumn{3}{|c|}{$50^{\circ} \mathrm{C}$} & \multicolumn{3}{|c|}{$60^{\circ} \mathrm{C}$} & \multicolumn{3}{|c|}{$70^{\circ} \mathrm{C}$} \\
\hline & & $\mathrm{R}^{2}$ & $\mathrm{X}^{2}$ & RMSE & $\mathrm{R}^{2}$ & $\mathrm{X}^{2}$ & RMSE & $\mathrm{R}^{2}$ & $\mathrm{X}^{2}$ & RMSE \\
\hline \multirow{3}{*}{$\mathrm{C}$} & Two-term & 0.99331 & 0.00006 & 0.00619 & 0.99306 & 0.00010 & 0.00779 & 0.99102 & 0.00021 & 0.01160 \\
\hline & Rational & 0.99067 & 0.00008 & 0.00731 & 0.99831 & 0.00002 & 0.00384 & 0.98913 & 0.00026 & 0.01276 \\
\hline & Sigmoid & 0.99485 & 0.00005 & 0.00543 & 0.99838 & 0.00002 & 0.00377 & 0.98668 & 0.00031 & 0.01411 \\
\hline \multirow{3}{*}{ CAP } & Two-term & 0.99596 & 0.00003 & 0.00453 & 0.99265 & 0.00012 & 0.00868 & 0.98943 & 0.00026 & 0.04806 \\
\hline & Rational & 0.99237 & 0.00006 & 0.00622 & 0.99706 & 0.00005 & 0.00549 & 0.97986 & 0.00063 & 0.06633 \\
\hline & Sigmoid & 0.99152 & 0.00007 & 0.00656 & 0.99684 & 0.00005 & 0.00569 & 0.99257 & 0.00023 & 0.04037 \\
\hline \multirow{3}{*}{ SP } & Two-term & 0.99774 & 0.00002 & 0.00333 & 0.98155 & 0.00033 & 0.01440 & 0.99572 & 0.00012 & 0.02944 \\
\hline & Rational & 0.99806 & 0.00001 & 0.00308 & 0.99697 & 0.00005 & 0.00185 & 0.99337 & 0.00019 & 0.03661 \\
\hline & Sigmoid & 0.99751 & 0.00002 & 0.00349 & 0.99678 & 0.00006 & 0.00190 & 0.99582 & 0.00012 & 0.02910 \\
\hline \multirow{3}{*}{ FP } & Two-term & 0.99847 & 0.00002 & 0.00347 & 0.99583 & 0.00014 & 0.00927 & 0.99701 & 0.00010 & 0.00802 \\
\hline & Rational & 0.99880 & 0.00001 & 0.00308 & 0.98859 & 0.00004 & 0.01534 & 0.99746 & 0.00009 & 0.00739 \\
\hline & Sigmoid & 0.99829 & 0.00002 & 0.00367 & 0.99715 & 0.00009 & 0.00767 & 0.99746 & 0.00009 & 0.00739 \\
\hline \multirow{2}{*}{ S } & \multirow{2}{*}{ Model } & \multicolumn{3}{|c|}{$90 \mathrm{~W}+50^{\circ} \mathrm{C}$} & \multicolumn{3}{|c|}{$90 \mathrm{~W}+60^{\circ} \mathrm{C}$} & \multicolumn{3}{|c|}{$90 \mathrm{~W}+70^{\circ} \mathrm{C}$} \\
\hline & & $\mathrm{R}^{2}$ & $\mathrm{X}^{2}$ & RMSE & $\mathrm{R}^{2}$ & $\mathrm{X}^{2}$ & RMSE & $\mathrm{R}^{2}$ & $\mathrm{X}^{2}$ & RMSE \\
\hline \multirow{3}{*}{$\mathrm{C}$} & Two-term & 0.97743 & 0.00255 & 0.04123 & 0.98241 & 0.00222 & 0.03851 & 0.97781 & 0.00328 & 0.04679 \\
\hline & Rational & 0.95488 & 0.00510 & 0.05830 & 0.97753 & 0.00284 & 0.04353 & 0.96641 & 0.00515 & 0.05479 \\
\hline & Sigmoid & 0.98952 & 0.00118 & 0.02809 & 0.98591 & 0.00178 & 0.03447 & 0.99592 & 0.00062 & 0.01908 \\
\hline \multirow{3}{*}{ CAP } & Two-term & 0.97272 & 0.00284 & 0.04254 & 0.97676 & 0.00352 & 0.04730 & 0.96869 & 0.00536 & 0.05840 \\
\hline & Rational & 0.94718 & 0.00551 & 0.05920 & 0.96960 & 0.00460 & 0.05410 & 0.94876 & 0.00877 & 0.07470 \\
\hline & Sigmoid & 0.99413 & 0.00061 & 0.01973 & 0.99301 & 0.00106 & 0.02595 & 0.99706 & 0.00050 & 0.01789 \\
\hline \multirow{3}{*}{ SP } & Two-term & 0.97245 & 0.00296 & 0.04524 & 0.98592 & 0.00177 & 0.03502 & 0.97852 & 0.00297 & 0.04351 \\
\hline & Rational & 0.91160 & 0.00949 & 0.08104 & 0.96983 & 0.00379 & 0.05125 & 0.97525 & 0.00343 & 0.04671 \\
\hline & Sigmoid & 0.99360 & 0.00069 & 0.02180 & 0.97414 & 0.00325 & 0.04745 & 0.98793 & 0.00167 & 0.03261 \\
\hline \multirow{3}{*}{ FP } & Two-term & 0.97500 & 0.00281 & 0.04331 & 0.97714 & 0.00259 & 0.04063 & 0.97624 & 0.00333 & 0.04603 \\
\hline & Rational & 0.95303 & 0.00529 & 0.05936 & 0.96144 & 0.00438 & 0.05277 & 0.96698 & 0.00463 & 0.05427 \\
\hline & Sigmoid & 0.98711 & 0.00145 & 0.03109 & 0.97943 & 0.00233 & 0.03853 & 0.96024 & 0.00557 & 0.05956 \\
\hline
\end{tabular}

S: Sample, C: Control, CAP: citric acid pretreatment, SP: sucrose pretreatment, FP: Freezing pretreatment, $\mathrm{R}^{2}$ : Determination coefficient, $\chi 2:$ Reduced chi-square, RMSE: Root mean square error

Table 3. Effective moisture diffusivities and activation energies of samples

\begin{tabular}{|c|c|c|c|c|c|c|c|c|}
\hline \multirow{2}{*}{ S } & \multicolumn{3}{|c|}{$\mathrm{D}_{\mathrm{eff}}\left(\mathrm{m}^{2} / \mathrm{s}\right)$} & \multirow{2}{*}{$\frac{\mathrm{E}_{\mathrm{a}}(\mathrm{kJ} / \mathrm{mol})}{-}$} & \multicolumn{3}{|c|}{$\mathrm{D}_{\mathrm{eff}}\left(\mathrm{m}^{2} / \mathrm{s}\right)$} & $\mathrm{E}_{\mathrm{a}}(\mathrm{kJ} / \mathrm{mol})$ \\
\hline & $50^{\circ} \mathrm{C}$ & $60^{\circ} \mathrm{C}$ & $70^{\circ} \mathrm{C}$ & & $90 \mathrm{~W}+50^{\circ} \mathrm{C}$ & $90 \mathrm{~W}+60^{\circ} \mathrm{C}$ & $90 \mathrm{~W}+70^{\circ} \mathrm{C}$ & - \\
\hline $\mathrm{C}$ & $1.724 \times 10^{-10}$ & $2.333 \times 10^{-10}$ & $3.347 \times 10^{-10}$ & 30.541 & $4.260 \times 10^{-10}$ & $9.432 \times 10^{-10}$ & $1.055 \times 10^{-9}$ & 42.101 \\
\hline CAP & $3.043 \times 10^{-10}$ & $4.057 \times 10^{-10}$ & $4.158 \times 10^{-10}$ & 13.386 & $9.128 \times 10^{-10}$ & $1.116 \times 10^{-9}$ & $1.247 \times 10^{-9}$ & 14.437 \\
\hline $\mathrm{SP}$ & $3.854 \times 10^{-10}$ & $4.057 \times 10^{-10}$ & $4.564 \times 10^{-10}$ & 7.761 & $1.359 \times 10^{-9}$ & $1.592 \times 10^{-9}$ & $1.724 \times 10^{-9}$ & 11.002 \\
\hline FP & $4.868 \times 10^{-10}$ & $4.970 \times 10^{-10}$ & $5.173 \times 10^{-10}$ & 2.785 & $1.552 \times 10^{-9}$ & $1.592 \times 10^{-9}$ & $1.805 \times 10^{-9}$ & 6.929 \\
\hline
\end{tabular}

S: Sample, C: Control, CAP: citric acid pretreatment, SP: Sucrose pretreatment, FP: Freezing pretreatment, $\mathrm{D}_{\mathrm{e}}$ : Effective moisture diffusivity $\left(\mathrm{m}^{2} / \mathrm{s}\right)$, $\mathrm{R}^{2}$ : Determination coefficient, $\mathrm{E}_{\mathrm{a}}$ : Activation energy $(\mathrm{kJ} / \mathrm{mol})$ 
The values of $\mathrm{D}_{\text {eff }}$ which are the indicators of moisture, vapor and surface diffusion, and capillary and viscous flow (Dehghannya et al., 2018a) for white sweet cherries were shown in Table 3. Drying temperature had an enhancing effect on $\mathrm{D}_{\text {eff }}$ because of faster water evaporation and predrying treatments also influenced effective moisture removal from the product positively. In general $\mathrm{D}_{\text {eff }}$ levels were in the following order: frozen $>$ sucrose pretreated $>$ citric acid pretreated > control and values belonged to MW-HA drying were always greater than HA drying. Likewise, Dehghannya et al. (2018b) stated that the osmotic solution augmented $D_{\text {eff }}$ in three-stage hybrid osmotic-intermittent microwave-convective drying of apple when compared to the control. Up to a specific solution concentration, sucrose gain into the product can be responsible for higher $D_{\text {eff }}$ values by the virtue of developed texture resistance (Dehghannya et al., 2018a) and similar approach may be valid for citric acid. The minimum value was $1.724 \times 10^{-10} \mathrm{~m}^{2} / \mathrm{s}$ at $50^{\circ} \mathrm{C}$ in HA drying and $4.260 \times 10^{-10} \mathrm{~m}^{2} / \mathrm{s}$ at $50^{\circ} \mathrm{C}$ combined with $90 \mathrm{~W}$ in MWHA drying of white sweet cherries.

When a driving force exists, the required energy for water molecules which pass through the barrier is defined as $E_{a}$ and a lower value of $E_{a}$ means higher moisture diffusion in dehydration (Çelen, 2019). The $E_{a}$ amounts of HA and MW-HA dried samples with citric acid, sucrose and freezing pretreated, and control sample were found to be $30.541,13.386,7.761,2.785$ and 42.101, 14.437, $11.002,6.929 \mathrm{~kJ} / \mathrm{mol}$, respectively (Table 3). The $\mathrm{E}_{\mathrm{a}}$ was reported between $12.7-110 \mathrm{~kJ} / \mathrm{mol}$ in the literature (Zogzas et al., 1996). The pretreated white sweet cherries indicated lower $\mathrm{E}_{\mathrm{a}}$ in both drying techniques and this finding was currently in line with Doymaz and Kipcak's study (2018). Furthermore, microwave application caused an increase in $E_{a}$, despite of having comparably higher $D_{\text {eff }}$ values. Similar trend was declared by Deng et al. (2018) in red pepper drying and Motevali et al. (2016) in drying of mint leaves. Deng et al. (2018) claimed that the greater susceptibility of $D_{\text {eff }}$ to temperature variations led to that discrepancy.

\section{Color}

Consumer choices and marketing value are primarily based on color characteristics. Thermal operations induce color degradation; hence, the extent and conditions (temperature, oxygen and moisture stages etc.) of the process play important roles within this context (Qing-Guo et al., 2006). Non-enzymatic browning (Maillard reaction, chemical oxidation of phenols and caramelization) may occur during drying (Deng et al., 2019; Önal et al., 2019) and technique of thermal operation is also effective. As shown in Figure 2, the type of drying and pretreatments had a considerable impact on the color properties of white sweet cherries. It is necessary to point out that the changes in total color and YI values were different inside and outside of the product owing to the exocarp and mesocarp structures.

$\Delta \mathrm{E}$ was classified by Cserhalmi et al. (2006) under five groups as; (1) not noticeable, (2) slightly noticeable, (3) noticeable, (4) well visible and (5) great. When considering the data of dried fruits, results remarked that some of $\Delta \mathrm{E}$ levels were belonged to well visible and great categories, although the most of them were apart from the aforementioned viewpoint. Furthermore, a meaningful change in color was realized in case of MW-HA drying and this can be associated with both increasing product temperature, and continuous and combined application of HA and MW which intensified the negative effect of heating. In contrast to that process, longer drying time increased $\Delta \mathrm{E}$ in HA drying (Szadzińska et al., 2016). Zhoa et al. (2019) investigated the impact of sodium carbonate on color of air dried wolfberries, and $\Delta \mathrm{E}$ values were calculated 13,16 and 26 at 40,50 and $60^{\circ} \mathrm{C}$ respectively, which were higher than our findings of HA drying. On the other hand, YI is strictly related to whiteness index, carotenoids, and food degradation by processing and exposure of physical factors such as oxygen, light and so on (Choo et al., 2020; Mocanu et al., 2020).
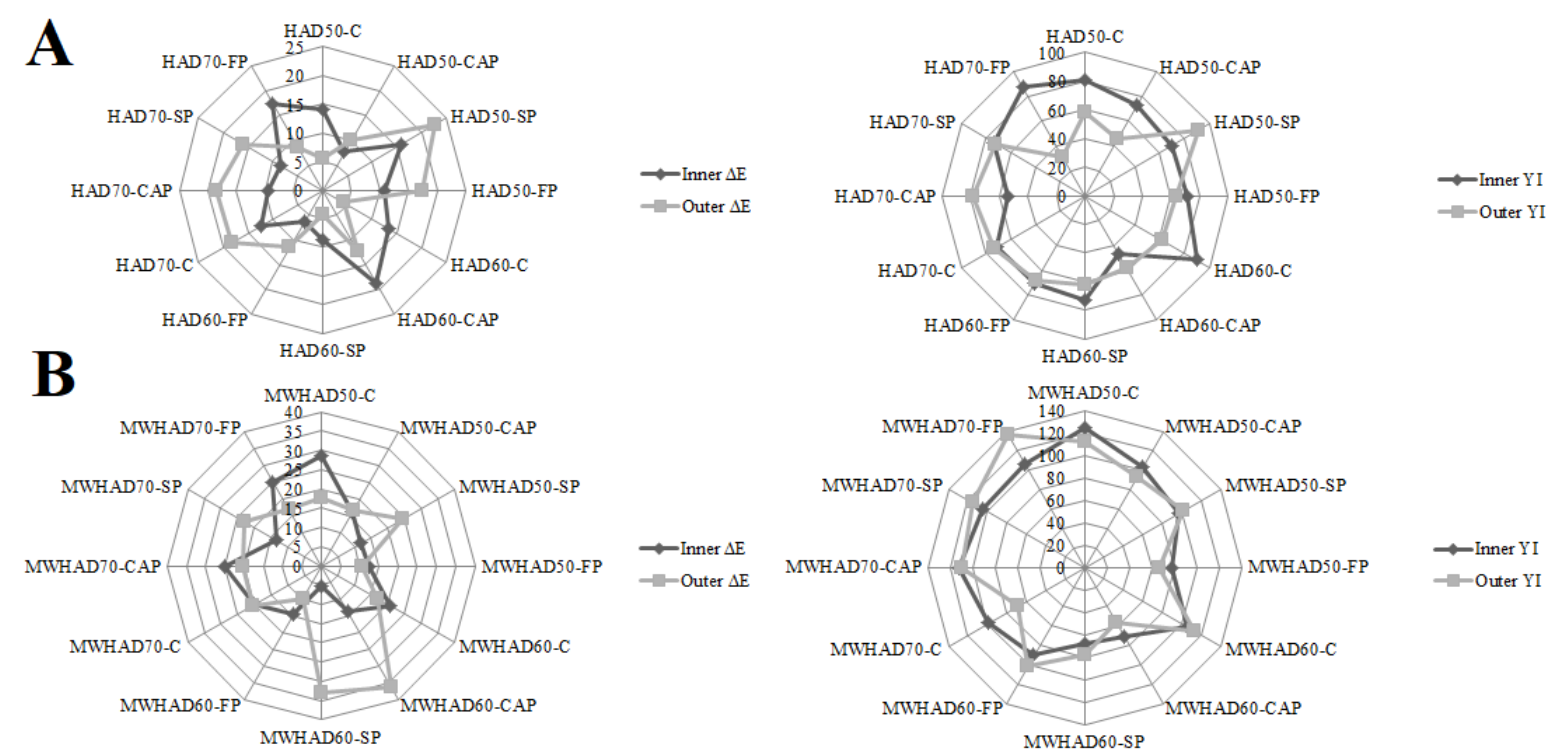

Figure 2. Total color change $(\Delta \mathrm{E})$ and yellowness index $(\mathrm{YI})$ values of $\mathrm{A}) \mathrm{HAD}, \mathrm{B}) \mathrm{MWHAD}$ samples HAD: Hot air dried, MWHAD: Microwave +hot air dried, 50, 60 and 70: Temperature levels $\left({ }^{\circ} \mathrm{C}\right), \mathrm{C}$ : Control, CAP: Citric acid pretreatment, SP: Sucrose pretreatment, FP: Freezing pretreatment 


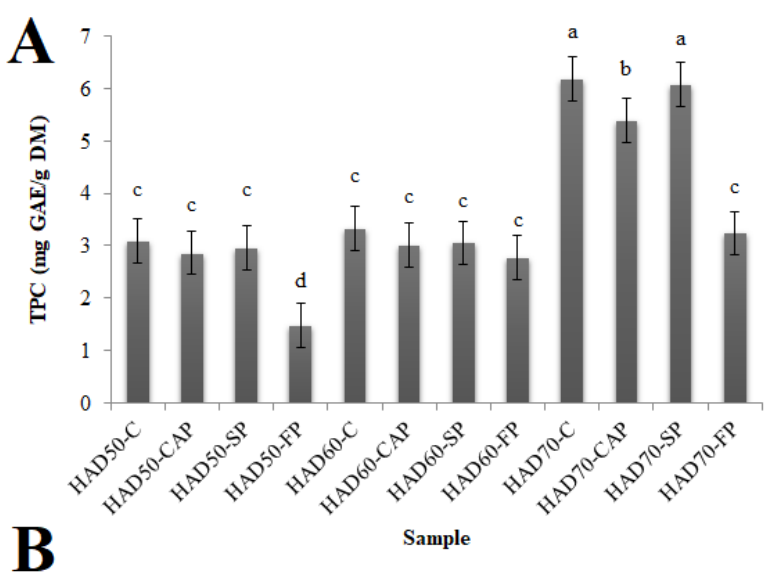

These observations demonstrated that MW application prior to HA drying enhanced TPC in stark gold variety, similarly to sour cherry (Horuz et al., 2017) and ginger (An et al., 2016). Probably, longer drying times may destroy phenolic compounds in HA alone drying and MW energy is able to cause several damages in cell structure, so polyphenols can be easily transferred into the extraction medium (Kubra and Rao, 2012).

Freezing pretreatment induced dramatically lower TPC in especially HA drying. The quality characteristics of a frozen material may be negatively influenced from many factors such as the size and distribution of ice crystals and, volumetric and accordingly phase variations in water. All of them can cause potential stress mechanisms in tissues, while phase change (from water to ice) occurs. Hence, damaged cellular walls may reduce the bioactivity (Paciulli et al., 2015; Vallespir et al., 2019). Citric acid and sucrose pretreatments always demonstrated promising results in MW-HA drying, as higher phenolic level was specified when compared to control. As was reported by Yao et al. (2020), cyclic structure of pretreatment agents might restrict oxidation reactions which can be promoted by polyphenol oxidase enzyme. In case of MW drying, nonenzymatic reactions may also trigger the conversion of phenolic precursors to the new phenolic molecules (Soong and Barlow, 2004). Moreover, an increment in the degree of temperature intensified the effect of both citric acid and sucrose. On the contrary, the related pretreatments did not have a significant impact on HA drying $(\mathrm{P}>0.05)$, except $70^{\circ} \mathrm{C}$. The longer drying times and exposure to air may be associated with this conflicting finding.

Figure 3. TPC levels of A) HAD, B) MWHAD white sweet cherries

HAD: Hot air dried, MWHAD: Microwave+hot air dried, 50, 60 and 70: Temperature levels $\left({ }^{\circ} \mathrm{C}\right), \mathrm{C}$ : Control, CAP: Citric acid pretreatment, SP: Sucrose pretreatment, FP: Freezing pretreatment

Different small letters indicate significant differences between samples $(\mathrm{P}<0.05)$.

Unlike $\Delta \mathrm{E}$, the great variations were not observed in inner and outer YI values of both HA and MW-HA dried samples. The enhanced YI can be assigned to carotenoid disintegration, the accumulation of other pigments due to higher temperature which signs the sensitivity of fruit (Kotwaliwale et al., 2007) and accordingly final products of browning reactions (Mocanu et al., 2020). Mittal et al. (2012) found the variations of YI in MW dried whole and sliced mushrooms higher than HA dried ones, which were currently in line with our study. High surface temperature in MW drying was attributed to this situation.

\section{TPC}

The antioxidant activity of a biological material is strongly related to its phenolic compounds. Thus, the TPC content clearly depicts the bioactivity of both HA and MWHA dried white sweet cherries (Figure 3). A significantly higher level of TPC was determined in all dried samples ( $\mathrm{P}<0.05)$, when compared with $0.71 \pm 0.20 \mathrm{mg} \mathrm{GAE} / \mathrm{g} \mathrm{DM}$ (or $10.31 \pm 2.42 \mathrm{mg} \mathrm{GAE} / 100 \mathrm{~g}$ fresh weight $(\mathrm{FW})$ ) in fresh one. Although, thermal processing inclined the degradation of some bioactives because of the activity of polyphenol oxidase enzyme, drying operation developed the density of polyphenols (Donovan et al., 1998). The TPCs of MW-HA dried samples generally differed from each other importantly $(\mathrm{P}<0.05)$, with a more than one and a half times higher concentration of polyphenols in other technique.

\section{Conclusion}

Wet infusions of citric acid and sucrose as pretreatments and as well freezing application reduced drying times of white sweet cherries in both dehydration methods. MW-HA combination technique enabled comparably shorter drying time than the conventional one. Page, modified Page, sigmoid, Midilli et al., Henderson and Pabis, two-term, Wang-Singh, parabolic, cubic, rational and Vega-Galvez equations were fitted into drying data and the best results were obtained by two-term, rational and sigmoid models. Unfortunately, the statistical outcomes of MW-HA drying were not as good as HA drying. Temperature, microwave heating and pretreatment procedures influenced dramatically $D_{\text {eff }}$ and $E_{a}$ values of samples. $\Delta \mathrm{E}$ and $\mathrm{YI}$ levels were important for the quality of dried white sweet cherries and striking findings were procured. Frozen products had faster color deterioration than the others. TPC was enhanced by drying processes when compared to fresh fruit, and MW-HA drying technique was more effective in this way.

\section{Funding}

This study was financially supported by Scientific Research Projects Unit of Osmaniye Korkut Ata University with the project number OKÜBAP-2019-PT2-005.

\section{Conflict of Interest}

The authors declared no conflicts of interest for this work. 


\section{References}

Adiletta G, Wijerathne C, Senadeera W, Russo, P, Crescitelli A, Matteo M Di, 2018. Dehydration and rehydration characteristics of pretreated pumpkin slices. Italian Journal of Food Science, 30: 684-706. https://doi.org/10.14674/IJFS-1176

An K, Zhao D, Wang Z, Wu J, Xu Y, Xiao G, 2016. Comparison of different drying methods on Chinese ginger (Zingiber officinale Roscoe): Changes in volatiles, chemical profile, antioxidant properties, and microstructure. Food Chemistry, 197(B), 1292-1300. http://dx.doi.org/10.1016/j.foodchem.2015.11.033

Antal T, Figiel A, Kerekes B, Sikolya L, 2011. Effect of drying methods on the quality of the essential oil of spearmint leaves (Mentha spicata L.). Drying Technology, 29: 1836-1844. https://doi.org/10.1080/07373937.2011.606519

AOAC. 1990. Official methods of analysis of the Association of Official Analytical Chemists. $15^{\text {th }}$ edition. Washington, DC, Association of Official Analytical Chemists.

Donovan JL, Meyer AS, Waterhouse AL, 1998. Phenolic composition and antioxidant activity of prunes and prune juice (Prunus domestica). Journal of Agricultural and Food Chemistry, 46(4), 1247-1252. https://doi.org/10.1021/jf970831x

Crank J, 1975. Diffusion in a plane sheet. pp. 42-61. In: The Mathematics of Diffusion. Clarendon Press, Inc., Oxford, London, UK

Cserhalmi Z, Sass-Kiss Á, Tóth-Markus M, Lechner N, 2006. Study of pulsed electric field treated citrus juices. Innovative Food Science and Emerging Technologies, 7: 49-54. https://doi.org/10.1016/j.ifset.2005.07.001

Çelen S, 2019. Effect of microwave drying on the drying characteristics, color, microstructure, and thermal properties of Trabzon persimmon. Foods, 8: 84. https://doi.org/ 10.3390/foods 8020084

Dandamrongrak R, Mason R, Young G, 2003. The effect of pretreatments on the drying rate and quality of dried bananas. International Journal of Food Science \& Technology, 38: 877-882. https://doi.org/10.1046/j.0950-5423.2003.00753.x

Dehghannya J, Bozorghi S, Heshmati MK, 2018a. Low temperature hot air drying of potato cubes subjected to osmotic dehydration and intermittent microwave: drying kinetics, energy consumption and product quality indexes. Heat and Mass Transfer, 54: 929-954. https://doi.org/ 10.1007/s00231-017-2202-5

Dehghannya J, Farshad P, Khakbaz Heshmati M, 2018b. Three-stage hybrid osmotic-intermittent microwave-convective drying of apple at low temperature and short time. Drying Technology, 36 : 1982-2005. https://doi.org/10.1080/07373937. 2018.1432642

Deng LZ, Mujumdar AS, Zhang Q, Yang XH, Wang J, Zheng ZA, Gao ZJ, Xiao HW, 2019. Chemical and physical pretreatments of fruits and vegetables: Effects on drying characteristics and quality attributes-a comprehensive review. Critical Reviews in Food Science and Nutrition, 59(9): 1408-1432. https://doi.org/ 10.1080/10408398.2017.1409192

Deng LZ, Yang XH, Mujumdar AS, Zhao JH, Wang D, Zhang Q, Wang J, Gao ZJ, Xiao HW, 2018. Red pepper (Capsicum annuum L.) drying: Effects of different drying methods on drying kinetics, physicochemical properties, antioxidant capacity, and microstructure. Drying. Technology, 36: 893907. https://doi.org/10.1080/07373937.2017.1361439

Doymaz I, İsmail O, 2011. Drying characteristics of sweet cherry. Food and Bioproducts Processing, 89: 31-38. https://doi.org/10.1016/j.fbp.2010.03.006

Doymaz I, Kipcak AS, 2018. Effect of pre-treatment and air temperature on drying time of cherry tomato. Journal of Thermal Engineering, 4: 1648-1655. https://doi.org/ 10.18186/journal-of-thermal-engineering.364489

Finaud J, Lac G, Filaire E 2006. Oxidative stress: Relationship with exercise and training. Sports Medicine, 36(4): 327-358.
Franceschinis L, Sette P, Schebor C, Salvatori D, 2015. Color and bioactive compounds characteristics on dehydrated sweet cherry products. Food and Bioprocess Technology, 8: 17161729. https://doi.org/10.1007/s11947-015-1533-9

Gonçalves AC, Campos G, Alves G, Garcia-Viguera C, Moreno DA, Silva LR, 2020. Physical and phytochemical composition of 23 Portuguese sweet cherries as conditioned by variety (or genotype). Food Chemistry, 335: 127637. https://doi.org/10.1016/j.foodchem.2020.127637

Haghi AK, Zerafat Angiz F, 2007. Heat and mass transfer in thermal drying of wool: a theoretical approach. The Proceedings of the $5^{\text {th }}$ Asia-Pacific Drying Conference, 443448. https://doi.org/10.1142/9789812771957_0065

Henderson SM, 1974. Progress in developing the thin layer drying equation. Transactions of the ASAE, 17: 1167-1172.

Horuz E, Bozkurt H, Karataş H, Maskan M, 2017. Effects of hybrid (microwave-convectional) and convectional drying on drying kinetics, total phenolics, antioxidant capacity, vitamin $\mathrm{C}$, color and rehydration capacity of sour cherries. Food Chemistry, 230: 295-305. https://doi.org/10.1016/ j.foodchem.2017.03.046

Kubra IR, Rao LJM, (2012). Microwave drying of ginger (Zingiber officinale Roscoe) and its effects on polyphenolic content and antioxidant activity. International Journal of Food Science \& Technology, 47: 2311-2317. https://doi.org/ 10.1111/j.1365-2621.2012.03104.X

Kumar C, Karim MA, 2019. Microwave-convective drying of food materials: A critical review. Critical Reviews in Food Science and Nutrition, 59(3): 379-394. https://doi.org/ 10.1080/10408398.2017.1373269

Li D, Zhu Z, Sun DW, 2018. Effects of freezing on cell structure of fresh cellular food materials: A review. Trends in Food Science \& Technology, 75: 46-55. https://doi.org/ 10.1016/j.tifs.2018.02.019

Li X, Wasila H, Liu L, Yuan T, Gao Z, Zhao B, Ahmad I, 2015. Physicochemical characteristics, polyphenol compositions and antioxidant potential of pomegranate juices from 10 Chinese cultivars and the environmental factors analysis. Food Chemistry, 175: 575-584. https://doi.org/ 10.1016/j.foodchem.2014.12.003

Miraei Ashtiani SH, Sturm B, Nasirahmadi A, 2018. Effects of hot-air and hybrid hot air-microwave drying on drying kinetics and textural quality of nectarine slices. Heat Mass Transfer, 54: 915-927. https://doi.org/10.1007/s00231-0172187-0

Mittal TC, Sharma SR, Muker JS, Gupta SK, 2012. Drying behaviour and change in colour and textural properties of mushroom during drying. International Journal of Food Engineering, 8(1): article 10. https://doi.org/10.1515/15563758.1696

Mohammed FS, Günal S, Sabik AE, Akgül H, Sevindik M, 2020. Antioxidant and antimicrobial activity of Scorzonera papposa collected from Iraq and Turkey. KSU Journal of Agriculture and Nature, 23(5): 1114-1118. https://doi.org/ 10.18016/ ksutarimdoga.vi.699457.

Motevali A, Chayjan RA, Salari K, Taghizadeh A, 2016. Studying the effect of different drying bed on drying characteristic of mint leaves. Chemical Product and Process Modeling, 11: 231-239. https://doi.org/10.1515/cppm-2015-0045

Mujic I, Zekovic Z, Lepojevic Z, Vidovic S, Zivkovic J, 2010. Antioxidant properties of selected edible mushroom species. Journal Central European Agriculture, 11(4): 387-392.

Önal B, Adiletta G, Crescitelli A, Di Matteo M, Russo P, 2019. Optimization of hot air drying temperature combined with pre-treatment to improve physico-chemical and nutritional quality of 'Annurca' apple. Food and Bioproducts Processing, 115: 87-99. https://doi.org/10.1016/ j.fbp.2019.03.002 
Paciulli M, Ganino T, Pellegrini N, Rinaldi M, Zaupa M, Fabbri A, Chiavaro E, (2015). Impact of the industrial freezing process on selected vegetables - Part I. Structure, texture and antioxidant capacity. Food Research International, 74, 329337. https://doi.org/10.1016/j.foodres.2014.04.019

Page GE, 1949. Factors influencing the maximum rates of air drying shelled corn in thin layers. Purdue University, West Lafayette.

Pathare PB, Opara UL, Al-Said FAJ, 2013. Colour measurement and analysis in fresh and processed foods: A review. Food and Bioprocess Technology, 6: 36-60. https://doi.org/ 10.1007/s11947-012-0867-9

Pirone BN, De Michelis A, Salvatori DM, 2014. Pretreatments effect in drying behaviour and colour of mature and immature "Napolitana" sweet cherries. Food and Bioprocess Technology, 7: 1640-1655. https://doi.org/10.1007/s11947013-1238-x

Qing-Guo H, Min Z, Mujumdar A, Wei-Hua D, Jin-Cai S, 2006. Effects of different drying methods on the quality changes of granular edamame. Drying Technology, 24: 1025-1032. https://doi.org/10.1080/07373930600776217

Sevindik M, Akgul H, Pehlivan M, Selamoglu Z. 2017. Determination of therapeutic potential of Mentha longifolia ssp. Longifolia. Fresenius Environmental Bulletin, 26(7): 4757-4763.

Staniszewska I, Liu ZL, Zhou Y, Zielinska D, Xiao HW, Pan Z, Zielinska M, 2020. Microwave-assisted hot air convective drying of whole cranberries subjected to various initial treatments. LWT-Food Science and Technology, 133: 109906. https://doi.org/10.1016/j.lwt.2020.109906

Szadzińska J, Łechtańska J, Pashminehazar R, Kharaghani A, Tsotsas E, 2019. Microwave- and ultrasound-assisted convective drying of raspberries: Drying kinetics and microstructural changes. Drying Technology, 37: 1-12. https://doi.org/10.1080/07373937.2018.1433199

Vakula A, Pavlić B, Pezo L, Tepić Horecki A, Daničić T, Raičević L, Ljubojević M, Šumić Z, 2020. Vacuum drying of sweet cherry: Artificial neural networks approach in process optimization. Journal of Food Processing and Preservation, 44: e14863. https://doi.org/10.1111/jfpp.14863
Vallespir F, Rodríguez Ó, Eim VS, Rosselló C, Simal S, (2019). Effects of freezing treatments before convective drying on quality parameters: Vegetables with different microstructures. Journal of Food Engineering, 249: 15-24. https://doi.org/10.1016/j.jfoodeng.2019.01.006

Wang Y, Li X, Chen X, Li B, Mao X, Miao J, Zhao C, Huang L, Gao W, 2018. Effects of hot air and microwave-assisted drying on drying kinetics, physicochemical properties, and energy consumption of chrysanthemum. Chemical Engineering and Processing: Process Intensification, 129: 84-94. https://doi.org/10.1016/j.cep.2018.03.020

Wang Q, Li S, Han X, Ni Y, Zhao D, Hao J, 2019. Quality evaluation and drying kinetics of shitake mushrooms dried by hot air, infrared and intermittent microwave-assisted drying methods. LWT-Food Science and Technology, 107: 236242. https://doi.org/10.1016/j.lwt.2019.03.020

Zhao D, An K, Ding S, Liu L, Xu Z, Wang Z, 2014. Two-stage intermittent microwave coupled with hot-air drying of carrot slices: Drying kinetics and physical quality. Food and Bioprocess Technology, 7: 2308-2318. https://doi.org/ 10.1007/s11947-014-1274-1

Zhao D, Zhao C, Tao H, An K, Ding S, Wang Z, 2013. The effect of osmosis pretreatment on hot-air drying and microwave drying characteristics of chili (Capsicum annuum L.) flesh. International Journal of Food Science \& Technology, 48: 1589-1595. https://doi.org/10.1111/ijfs.12128

Zhao D, Wei J, Hao J, Han X, Ding S, Yang L, Zhang Z, 2019. Effect of sodium carbonate solution pretreatment on drying kinetics, antioxidant capacity changes, and final quality of wolfberry (Lycium barbarum) during drying. LWT-Food Science and Technology, 99: 254-261. https://doi.org/10.1016/j.lwt.2018.09.066

Zogzas NP, Maroulis ZB, Marinos-Kouris D, 1996. Moisture diffusivity data compilation in foodstuffs. Drying Technology, 14: 2225-2253. https://doi.org/10.1080/ 07373939608917205 